\title{
AO NOSSO QUERIDO RUBENS LIMONGI FRANÇA
}

\author{
Daisy Gogliano \\ Professora Doutora do Departamento de Direito Civil \\ da Universidade de São Paulo
}

Nesta Academia orgulhava-se Castro Alves de ouvir as preleções de um civilista nestas palavras: "O grande José Bonifácio!" Nós, não só ouvimos Rubens Limongi França, como o vivemos, o experimentamos, somos como Rubens Limongi França. Igualmente dizemos com orgulho: "O grande Rubens Limongi França"

Não vamos empregar o verbo no passado. Vamos empregá-lo no presente, pois o nosso mestre, o nosso mentor e amigo é atemporal. E quem nos dá esta lição de atemporalidade é o próprio Rubens Limongi França ao interpretar Castro Alves, dizendo: "O gênio ao manifestar-se, o faz fora do tempo, na medida em que atemporal é a energia que o suscita'

Típico dos heróis de inteligência superior, justamente por ser atemporal, sempre se congregam a gratidão e a afeição para com os amigos. É marcante o seu espírito de solidariedade, na ajuda a todos, o quanto pode. Sincero e acima de tudo sensivel, preocupa-se em não ferir, não magoar. Ético, por excelência, para com os colegas não lhes retira a autoridade publicamente. Sempre um gesto, sempre uma palavra acolhedora nos momentos de contrição. Sempre aquele sorriso que tudo ilumina e tudo acalma.

Acredita no Amor sublime que reconhece ser raro, mas que sela as almas para sempre, como diz na sua alusão a Castro Alves.

Por ser artista, pintor, escultor e poeta, canta em seus versos "como é certeza que possuo alma' Falamos hoje de alma para alma, seladas, ao nosso grande Rubens Limongi França! Essa alma benevolente e sábia, que perdoas os arroubos da juventude, que nos embala e nos conduz na redenção do Cristo, no nosso trabalho, que não pode parar e jamais esmorecer, por maior a dor, por maior o desamparo, na grande responsabilidade de não decepcionar.

O exemplo de mestre e amigo estão nas palavras que descrevem os momentos de contrição vividos por Castro Alves: "O único facho capaz de aclarar os caminhos, outra coisa não seria, senão a graça sobrenatural da fe" 
É a energia sagrada que faz de Rubens Limongi França um dos maiores civilistas desta Pátria e além dela é aquela fé no coração, do âmago da natureza das coisas, nessa Justeza, sempre perseguida. Títulos não lhe faltam: Professor Titular da Faculdade de Direito da Universidade de São Paulo; decano dos doutores da Pontifícia Universidade Católica de São Paulo; Professor Catedrático "Honoris Causa" da Universidad Nacional Mayor de San Marcos Lima, Perú; Titular da Academia Brasileira de Letras Jurídicas; Titular da Academia Paulista de Letras Jurídicas; Sócio Honorário do Instituto dos Advogados da Bahia; Professor da Escola de Magistratura de Pernambuco e acima de tudo nosso mentor, nosso amigo. Como jurista, palmo a palmo, no decorrer de suas obras, não descura da sacralização do Direito, como "ars boni et aequi"

A sua obra é grandiosa. Fruto de esforço continuado, que resiste a todos os embates. É a própria expressão da fé e honestidade científica, tão forte quanto a sua fé religiosa. Fé esta que também se traduz nos oferecimentos e louvores a Deus, nas dedicatórias e prefácios de sua obra.

O que se admira em Rubens Limongi França, entre tantos dons, tocantes e marcantes, é a sua excepcional capacidade de trabalho, a sua mentalidade organizada, que faz do seu "Manual" obra conceitual e sistematizada, por primazia. O "Direito Intertemporal" é a própria História do Direito ali decantada. Onde o caos persiste, onde a ilusão tal qual a miragem do deserto faz supor uma verdade, Rubens Limongi França nos leva e conduz à simplicidade, à objetividade, à clareza, por fim à beleza do Direito, completamente desvelada daquilo que ele graciosamente chama de "pôt pourri" de coquetel de pseudociência do Direito, dos comentadoresleguleios, daqueles que pensam que o Direito se resume na lei.

Rubens Limongi França é autêntico. É o descobridor da ordem a que estão submetidos todos os fenômenos jurídicos. É frase sua: " $O$ Direito Civil é a base do fenômeno jurídico"

A sua missão, forte e ao mesmo tempo dolorosa, firmada na convicção e na serenidade de quem está sempre a cumprir o seu dever, revela a altura, o cimo a que atingiu o pensamento jurídico brasileiro, pois faz Escola. O ápice foi a atingido com a mais extensa enciclopédia jurídica do mundo, a "Enciclopédia Saraiva do Direito" nas suas palavras, "a síntese do pensamento jurídico nacional" com a plêiade de juristas que se empenham em legar à Ciência do Direito ingente trabalho, em mão comum. Aquilo que Rubens Limongi França denomina: "A epopéia das Letras Jurídicas Nacionais" no agradecimento pujante e caloroso que faz a todos os 
colaboradores e participantes, "por mercê de Deus, Nosso Senhor, e pela grandeza de saber e de alma de todos...

Nos oferece em sua obra os instrumentos próprios, notadamente da Teoria Geral do Direito Civil, base e fundamento de tudo. As suas liçöes são límpidas e cristalinas, luzentes à luz do sol.

O Direito Natural em Rubens Limongi França assume particular importância. É o Direito Natural clássico, despido do racionalismo abstrato, eidético e extremado do jusnaturalismo. É aquele justo de Aristóteles e "do inigualável Cícero" "por natureza e por lei" como pilar sobre o qual se pode edificar uma Ciência Jurídica. No seu entender o Direito deve estar sempre a serviço do homem. O Direito deve comungar com todas as ciências. Diz: "A prata da casa é muito boa" quando se refere aos "turistas" do Direito que buscam doutrina alienígena, sem base e sem fundamento.

Como o professor, critica a mesmice falada em aula, nas expressões: "como diz o v. aresto; como diz o v. acórdão" ante a total incapacidade de pensar, daqueles que não sabem cobrir as lacunas do Direito. Jamais permitiu opiniões iniciadas como "eu acho" Contudentes são as críticas àqueles que parafraseam a leì; àqueles desligados da história e de nossas tradições mais sagradas que não podem ser descuradas. Sempre a bem da verdade histórica.

$\mathrm{O}$ que se admira é a radiosa criatividade do seu espirito fecundo, sempre em alerta constante isso é viver.

Se aos olhos do mundo tais expressões porventura induzem vaidade, outra coisa não são do que a sua firme convicção daquilo que é, daquilo que efetivamente pode, germe de sua autoconfiança e da sua coragem.

Pode-se dizer: imprime a sua "griffe" Essa "griffe" Limogiana, que se faz sentir nos seus discípulos na metodologia da pesquisa científica.

Nas suas mãos galgamos cordilheiras, buscando o cimo para uma indispensável visão universal. Nas suas mãos, descemos ao abissal, como escafandristas do Direito, na historiografia, descendo às origens mais profundas, no âmago das Instituições, onde o passado se faz presente, iluminando o devir Nas suas mãos sofremos angústias, dentro das próprias contingências humanas, sem qualquer revestimento ou capa que ilude, camufla e seduz.

Não vamos como Camões pedir licença "se lá no assento etéreo onde subistes, memória desta vida se consente... Ser eterno não é repousar no assento etéreo, não é repousar na eternidade. Ser eterno é viver em outrem e ser com outrem. 
É perdurar na memória do outro em poesia. A eternidade de Rubens Limongi França está nesse mundo que ele mesmo criou e abriu, nessa ampla possibilidade. Nessa clareira, nessa abertura imensa do seu ser, em benefício da Pátria e do Direito.

Vive em nós "uno corpore" Em nossa irrestrita admiração e veneração, em nossa profunda gratidão.

O nosso grande Rubens Limongi França!

Ouçamos Castro Alves:

Entra! O verso é uma pousada

Aos reis que perdidos vão

A estrofe - é a púrpura extrema

Último trono - é o poema

Último asilo - a canção.

São Paulo, novembro de 1999. 